\title{
Christian leadership in a South African township community: A reflection on nepotism and its impact on society
}

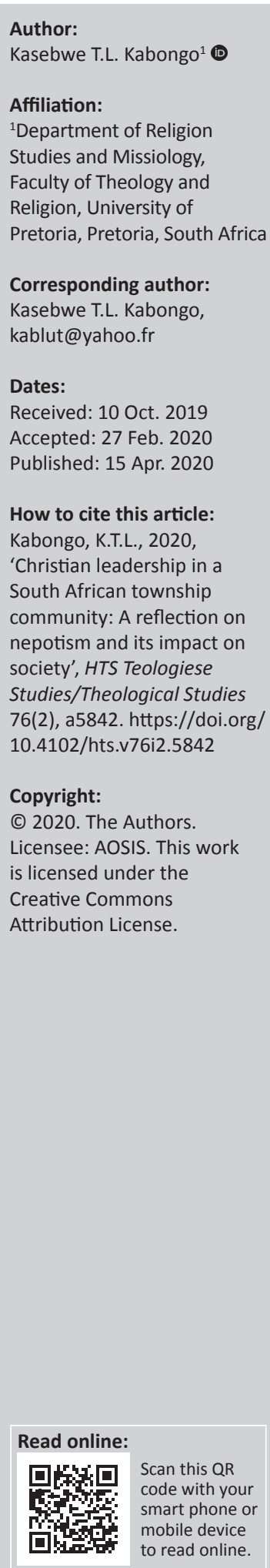

The author reflects on the reality of nepotism in Christian leadership as he has observed in the township of Soshanguve and many other African poverty-stricken communities he has lived in. The leadership of churches in those areas seems to run in the family. This model tends to have a disempowering effect on the other church members in terms of taking responsibility or initiating projects that could expand the impact of the church beyond the borders of its walls. This article recognises the positive impact of nepotism, but it mostly stresses on the negative impact of nepotism on the democratisation of power in the church and society. It uses music, a critical vehicle of knowledge acquisition in Africa, to stress upon the fact that Christian leaders should be equipped to participate in the common good, help in the empowerment of ordinary people around them, starting with their members and be altruistic, like Jesus, and work beyond the boundaries of their families.

Keywords: Democratisation; Inclusive; Music; Nepotism; Prophetic.

\section{Introduction}

Many South African townships, such as Soshanguve, have a lot of local churches. As stated by Kabongo (2019a):

In South Africa, a township refers to the often underdeveloped, racially segregated urban areas that, from the late 19th century until 1994, were reserved for non-whites. They were usually built on the periphery of towns and cities. (p. 1)

Soshanguve is a township spread over an area of $126.8 \mathrm{~km}^{2}$ and situated North of Pretoria, the South African administrative capital. It has different ethnic groups that represent the composition of its population. These groups include SOtho, SHAngaan, NGUni and Venda. Residents were divided according to their ethnic groups when they were resettled from various locations in 1974. While this was done to make administration easy for the apartheid government, it left a community that was divided and suspicious of each other. Until today, there are still remnants of the past, but there is also the integration of cultures (Pretoria News 2011:4).

Despite this reality, 'Christianity continues to grow and thrive in' this township at almost the same pace as 'the realities of poverty, tribalism, corruption and violence' (Katongole 2011:1). This reality exposes the impact of the church on the African society. This article stresses on the fact that the issues of Christian leadership and nepotism are factors contributing to the lack of prophetic witnessing of the church in society. Katongole (2011:7) points out that in many parts of Africa the church is a strong and powerful institution', yet it fails to positively participate in 'Africa's social history of violence, corruption, and poverty'. In many poverty-stricken communities, we see many local churches limiting leadership positions to family. Mashau and Kgatle (2019:6) remark that these 'churches are run as private and personal businesses by the lead pastor who passes on the baton to family members as if the church is their inheritance'. In contrast to this reality, many African musicians are singing tunes about patriotism, Africanism and othercenteredness, which reflect kingdom-like values found in the Bible. Yet, churches strongly encourage their members not to listen and learn from the content of this medium of communication because it shows the realities of the world.

Christians are advised to only listen to gospel music. This article reflects upon the fact: how can the church creatively deal with the issue of nepotism so that it can be a better prophetic witness in

Note: Special collection entitled Christian Leadership, sub-edited by Wessel Bentley (UNISA). 
society? It uses the hermeneutical method of research to deal with this question (Polit \& Beck 2008:244). For starters, the clarification of the key concepts of this article will be helpful in this interpretation.

\section{Clarification of key concepts}

The foundational understanding of Christian leadership is based on the Bible (Lk 22:26). Clinton (1988:14) sees Christian leadership as 'a dynamic process in which a person with Godgiven capacity influences a specific group of God's people toward His purposes for the group'. Mwambazambi and Banza (2014:2) see a Christian leader as a person 'who understands his or her moral responsibility as that of contributing to the transformation and enhancement of individuals and communities or organisations for a higher communal good'. Christian leadership is closely associated with the concept of servant leadership as stated in Luke 22:26. Bloom states that 'all professing Christians agree that a Christian leader should be a servant leader'. Bloom (2017) points out five characteristics of a servant leader:

1. A person who 'seeks the glory of his master'.

2. A person who 'sacrificially seeks the highest joy of those he/she serves'.

3. A person who 'forgoes his or her rights rather than obscures the gospel'.

4. A person 'who is not preoccupied with personal visibility and recognition'.

5. A person who 'anticipates and graciously accepts the time for his or her decrease' (p. 147).

Spears (2010:4) points out that 'servant leadership seeks to involve others in decision making. It is strongly based on ethical and caring behaviour'. It 'enhances the growth of' followers 'while improving the caring and quality of organizational life' (Spears 2010:5). Russell (2001:1) believes that servanthood has 'three aspects' to it: 'trust; appreciation of others; and empowerment of others other than your family'. Nepotism contradicts the latter statement because it is all about empowering only family or close associates.

Oakland (2013) points out that 'nepotism refers to the granting of employment to family members regardless of merit'. For Jaskiewicz et al. (2013:121), 'nepotism is an owner's or manager's preference for hiring family members rather than unrelated job applicants'. According to them, it is a common practice 'where families use their control to hire family members - therefore perpetuating family involvement over time and across generations' (Jaskiewicz et al. 2013:122). Some of the benefits of nepotism are knowledge capital, a high level of trust and a great sense of ownership. Lester, Postlewaite and Wright (2011:122) argue that 'many family firms practising nepotism meet or exceed industry profitability on average'. Some studies also show that 'family relationships - in contrast to relationships between nonfamily members - can be beneficial because they offer additional potential for generalized social exchanges that come with long-term commitment and indirect reciprocity' (Lester et al.
2011:122). Jaskiewicz et al. (2013:124) argue that nepotism makes it possible for businesses 'to inexpensively identify a pool of candidates for positions'. Because of their ties to the business owners, these new hires tend to be reliable and dedicated to their job. As a consequence, absenteeism no longer remains a problem.

However, Bizfluent.com (2019:1) argues that 'one of the disadvantages of nepotism in the workplace is resentment among co-workers' who are not related to the business owners. As soon as dedicated employees realise that 'competence is less important than bloodline relations, efficiency, effectiveness and good work ethics suffer' (Bizfluent.com 2019:1). When we move this conversation and learn from history, it appears that the practice of nepotism has been prevalent in the church for a long time. Oakland (2013:6) points out that the practice was prevalent as early as the middle ages in the Catholic church when popes 'would bestow high, ecclesiastical offices (such as that of cardinal) to nephews and illegitimate sons'. Hilary (1978:33) confirms this reality of nepotism during the Rennaissance church stating that 'papal nepotism...reached such proportions under the Colonna, Borgia, and Della Rovere popes as to appear an integral part of the papal administrative structure'. Gibson (1993:1) points out that nepotism has also been an issue in the church of England. According to him, nepotism has caused 'corruption and abuse that dogged the church after 1714' (Gibson 1993:1). As stated by Gibson (1993):

$[W]$ ithin the structure of patronage which included the recommendation of deserving clergy to the purveyors of patronage and the nomination of men of talent from the universities to the households of bishops. (p. 1)

In general, 'nepotism challenges the meritocratic ideal our society' should aspire to, says Joffe (2004:74). According to him, people should be put in leadership positions based on 'their abilities and achievements, rather than by advantages conferred through accidents of birth' (Joffe 2004:74). In African poverty-stricken communities such as the township of Soshanguve, the accident of birth seems to be a key factor in the transfer of Christian leadership. Shaw (2006:119) cautions regarding this reality by stating that Christian leadership should always be about imitating Jesus who included others beyond his earthly family in his leadership. He adds that Christian leaders should 'find significance in their relationship to God rather than through their status and positions'. Greenleaf (2002) also argues that Christian leaders should serve altruistically beyond one's family. According to him (Greenleaf 2002):

[T] he only authority deserving one's allegiance is the one that is freely and knowingly granted by the led, in response to and in proportion to the clearly servant stature of the leader. (n.p.)

A visionary statement stresses that 'in the future, the only viable institutions will be those that are servant led'. The current reality of nepotism in Christian leadership in a community such as Soshanguve poses serious questions about the viability of it as a prophetic witness in society. It is important to understand this context if any sustainable practice of altruism beyond nepotism has to be found. 


\section{A contextual understanding of Soshanguve}

As mentioned in the introduction, people from various cultures co-habited in Soshanguve. This co-habitation has also been a source of a lot of conflicts and mistrust among its residents. It appears that this issue of division and lack of trust within the population of Soshanguve is also reflected in the church leadership. The latter seems to have narrowed the circle of trust from an ethnic group to the family. While facing this reality, one can say that the church is barely functioning according to the values and principles it was founded on but has become a puppet of dominant social narratives.

Katongole (2017:21) attributes the cause of this situation to Christian theology. According to him 'Christian theology and practice have tended to readily and uncritically surrender to what is going on in the secular disciplines of politics, economics, and sociology'. Christian theology seems to be alienated by secular science. Mashau (2018:2) stresses that Christian theology should be 'a transformative encounter', not an alienating one. In addition, Mashau (2018) states that:

Christians are called to imitate God in all areas of life. The encountering God always works with human beings to accomplish His mission on earth. When God has encountered us in transforming ways, we are also expected to take the stands as God and radiate His being in the lives of others. We, therefore, become the same expressions of the very being that has transformed us. The church as a community of disciples is compelled to follow God by taking a stand against injustice and with wronged people. (p. 9)

Such a stand fits into the philosophy of ubuntu that black Africa is known for. This philosophy 'places communal interests above those of the individual, and where human existence is dependent upon interaction with others' (Mashau \& Kgatla 2019). Van Niekerk (2015:1) points out that ubuntu is connected to mutual respect, decency, civility and good manners. Tutu (1999:29) stresses that 'a person with ubuntu is diminished when others are humiliated or diminished, when others are tortured or oppressed, or treated as if they were less than who they are'.

However, this philosophy has always been an ideal rather than a reality when put against patriotism or Africanism. It is usually lived out within the context of an extended family, a clan and sometimes an ethnic group. Mofokeng (1987:10-11) alludes to ubuntu within a family-like framework, when he stresses that in black Africa, people 'who do not maintain contact with their ancestors are without anchor or direction in the world'. This family-centric approach is in contrast to the feeling of patriotism needed to build individual African countries and the continent as a whole. The Nobel Prize winner, Wole Soyinka (1972:1), even remarked 'that human beings are just destructive all over the world', including black Africans. There is ample evidence in support of this fact if we look at the genocide in Rwanda, Sudan, Democratic Republic of the (DR) Congo; civil wars and xenophobic violence in many parts of Africa. In this regard, black Africa has failed to live out 'the philosophy of $u b u n t u$ it is supposed to have been founded upon' (Van Niekerk 1994:3). Donovan (2005:37-38) captures this sad reality through the story where he went 'to preach the gospel' in one Tanzanian village. People came to Christ and acknowledged the importance of loving others, yet they refused to reconcile with a neighbouring clan of the same tribe they were in conflict with. Donavan wondered what it would look like to talk about nation-building, or participating in the common good to such people. This story shows the reality when it comes to relationships between local churches and residents of a certain section of the township of Soshanguve. These relationships are in many ways the opposite of ubuntu.

Looking back as far as possible, Beti (1977:11) makes a sombre remark that black Africans are known to be 'divided into countless small family clans, because of internal feuds and vendettas'. It is therefore naïve and problematic to believe that all black Africans resonate profoundly and constructively with the philosophy of ubuntu. African traditional societies were led by monarchies. The latter were privileged and had to lead society because of their blood affiliation. Sometimes, their privilege was acquired at the expense of the general population (Maathai 2009:27). Nowadays, we hear of some traditional leaders who are calling for the president of South Africa to free up a convicted fellow because they believe that the laws of the country should not apply to a traditional leader (News24 2019:1). It seems like the concept of ubuntu is applied to a homogenous society, which South Africa as a country or African as a continent is not. It, therefore, favours nepotism. In contrast, music seems to challenge the nepotistic practices seen in church leadership transfer in poor communities as well as in the African society in general. It seems to preach kingdom-like values in gentle, yet powerful ways.

\section{Music as a reminder of kingdom-like values}

Some African musicians have been pretty active at preaching patriotism and Africanism through their work. In his song, Freedom, Bobi Wine (2017) calls all Ugandans in their diversity to fight for freedom against dictatorship. His song raises awareness about the oppressive dictatorial system ordinary Ugandans are subjected to. This system seems to take away the fundamental rights of ordinary citizens and move them backward developmentally. He, therefore, calls upon Ugandans from all provinces, cities, towns and villages to join forces to fight for the liberation of their country.

The Ivorian Reggae musician, Alpha Blondy (2013), goes further than his home country in decrying the pain Africa as a continent is going through his song 'Ca me fait si mal' [it is painful]. He is hurt that Africans kill and destroy each other through civil wars, poor governance and greed. He points out that areas of conflict are on the increase; orphanages are mushrooming; weapon possession is uncontrolled; human right violations are rampant; the internally displaced and refugees are increasing; and the quality of life of general Africans is not improving. 
The Congolese Muhindo (2018) speaks directly of the poor state of leading his country of origin as well as the problems Africa as a continent is experiencing in his song 'Pas de president' [there is no president]. He states that the population from the east of the DR Congo, where he is from, is not cared for by their president and other political leaders. This area has been ravaged by war and militia in-fighting since 1996. This region is currently known as the world capital of rape, yet political leaders like to say that they have everything under control. He calls upon Congolese political leaders to be compassionate and fulfil their mandate as carers of society. He challenges all the other African leaders to be compassionate and tangibly care for their fellow citizens. He points out that many African leaders have accumulated a lot of wealth and assets in their countries of origin, but only invest in the west and create jobs for westerners. He calls for politicians to become servant leaders.

These three musicians allude to kingdom-like values Christians should be known for. Bobi Wine reminds us of the power of patriotism, which involves solidarity beyond our family ties. Mbembe (2017:xiv) stresses upon the fact that African leaders should help 'create a future that is inseparable from the notions of justice, dignity, and the in-common'. Alpha Blondy decries the reality of African self-destruction. He prays that Africa would discover its 'own agency and assets [which would] pave the way for self-reliance [and solidarity] in communities' (De Beer 2008:186). The unfortunate reality is that 'not all black people are necessarily committed to liberation and that the poor are not inherently egalitarian' (Ramphele 2017). Muhindo decries the absence of servant and caring leaders in Africa. Tshilenga (2016:ix) agrees with him in stating that there is a deficit of 'servant leadership in Africa', which is the greatest need right now for its development.

These musicians remind us of the kingdom like values of solidarity, agency and servant leadership. Yet, in the community where I live, the majority of church leaders discourage their members from listening to this kind of songs. They are labelled as worldly. Members are encouraged to only listen to gospel music. This is a dualism between the sacred and the profane, or the sacred and the secular. Du Toit (2010:432) views this as 'a dualistic spiritualisation of the gospel' which shelters Christians from the realities of the world around them that music brings up. My family house is sandwiched between a Pentecostal church and a tavern. I learn a lot from these two giants townships. Hirsch and Ford (2011:22) believe that Christians should live a 'salt and light in the name of Jesus Christ, regardless of situation, vocation, or location'. As salt and light in the world, they should never get bogged down with strict doctrinal or theological categories that shield them from realities around them. They should, instead, get involved in theological issues pertaining to the very life and death of their communities (Maluleke 2008:6566). Frost and Hirsch (2003:30) see this kind of involvement as a messianic spirituality. According to them, it is a 'spirituality of engagement with culture and the world in the same mode as the Messiah himself' (Frost \& Hirsch 2003:30). Christians are called to be connected to the world as a way of imitating Jesus. This messianic spirituality is taken from the Bible. In Nehemiah 2:17-18, for instance, Nehemiah deepened his relationship with God by mobilising his fellow Israelites to build the ruined walls of Jerusalem. In Jeremiah 29:1-12, the Israelites in exile deepen their relationship with God by incarnating in their host society and actively seeking its peace and prosperity. In Isaiah 58, social justice actions are seen as a spiritual discipline to be regularly practised by God's children. A Christian leadership formation that is in tune with societal issues that music engages has the potential to place the church as an influencer in society because it will be meaningfully prophetic.

\section{The church as a prophet in society}

This article understands prophetic ministry as the church's task to be and remain a tangible sign of hope and love in society under all circumstances. It is inspired by Brueggemann's (2001:3) take on prophetic ministry, which according to him has the task 'to nurture, nourish, and evoke a consciousness and perception alternative to the consciousness and perception of the dominant culture around us'. In the Christian culture, denominationalism and territorialism are the norms. They are nepotistic because they focus on the few and exclude the many when we look at the world. In actual fact, denominational distinctiveness is oftentimes just an accident of history. Most people belong to a denomination because that is their first spiritual home. The missiological foundation of Christianity is based on the great commission (Mt 28:16-20) that encourages followers of Jesus to go to the many (all nations) and not remain focused on the few (the small community of apostles). Oduyoye (1986:11) challenges us 'to engage the church passive attitudes toward social institutions'. According to her, Christian leaders should learn to transcend 'the current denominational divisions and competitions' such as Anglicanism, Methodism, Roman Catholicism, Baptism and so on which seem analogous to tribalism. Mwambazambi (2011:5-6) points out some inner divisions seen regularly within Christian leadership in poor African communities. According to him, 'they often experience schisms over internal struggles for power and of the personal ambitions and egoistic interests of their leaders in the race for material advantages' (Mwambazambi 2011:5-6). In addition, he (Mwambazambi 2011:5-6) stresses that 'the true enemy of the Christian mission is the harmful effect caused by the way' denominations 'treat each other as sects, according to a principle of exclusion...hence a sort of denominational Babelisation occurs'.

Katongole (2011:2-3) suggests that in order for denominations to learn to see one another as complements, not threat, theologians 'need to start telling alternative stories'. Katongole (2011) believes that:

$[W]$ ho we are, and who we are capable of becoming, depends very much on the stories we tell, the stories we listen to, and the stories we live.

Stories not only shape our values, aims, and goals; they define the range of what is desirable and what is possible. (pp. 2-3) 
For example, Africa is more of 'a set of stories about how people of the continent called Africa are located in the narrative that constitutes the modern world' than a place (Katongole 2011:3). Theologians are called to 'uncover the underlying stories of the key social institutions in Africa that affect both their performance and the types of characters they produce' (Katongole 2011:3).

As we communicate the message of love to people, especially those living in poverty, our aim should be the democratisation power. Ordinary people should be empowered to be agents of their own hope and answers to their own questions. I belong to a missional team that focuses on discipleship. In our communication of the message of love, we usually say and imply that Jesus is the answer. We are learning to carefully listen to the questions our neighbours are asking. Mwambazambi (2011:6) stresses that, in Africa, we usually hear people ask questions related 'to miseries, political and military conflicts, divisions, mediocrities, sterilities, despairs, catastrophes, xenophobia, derelictions, jealousies, capacity for destruction and powers of death'. We have not been able to answer these questions, but we are engaging these questions as participants in solution-seeking and invite these neighbours who ask these questions to journey alongside us. We believe that sustainable answers will be found if people who ask questions participate in finding them. This way of collaboratively interacting with answers our neighbours ask shapes us into being agents of the message of love.

\section{About being agents of the message of love}

Perkins defines the gospel as love lived out. According to him, 'the gospel is the love of God made visible, able to be touched and felt through physical agents of his kingdom' (Perkins 1993:44). It needs to be lived out with such intentionality that the kingdom of God will come on earth as it is in heaven (Mt 6:10). The process of love agency is meaningful when incarnational. This indicates that love is tangibly lived out in a particular context to be expanded beyond the borders of that context. In his book, A theology as big as the city, Ray Bakke talks about a 'process of transformational thinking and acting that occurred' in him in a 'way that developed a worldview that seeks biblical integrity and spiritual faithfulness' which broadened his theology from a personal approach to a citywide one (Bakke 2009:11). The Bible talks about how to be messengers of love beyond someone's comfort zone like Jeremiah 29:4-12 advises. This message has inspired some individuals to be the conduit of such a message in their context. This article will allude to three African Christian leaders.

- A South Sudanese bishop, Paride Taban, established the Kuron peace village to fight tribalism in a small way. In his work as a priest, he said, he found that tribalism was very high. People lived in their groups, often devaluing and discriminating against people from other communities. From personal experience of being discriminated against in his own country, he established this village on large farmland which had a school and other educational program, a clinic that ran several health programs that catered for everyone regardless of their religious or tribal affiliations (Katongole 2011:135-147).

- In Uganda, Angelina Atyam became an activist for a safe and peaceful environment for all, after her young girl was kidnapped by a rebel group in Northern Uganda. At some point, the rebels offered to buy her silence by freeing her daughter from captivity. She refused to be silenced because she believed that every child was her child and deserved freedom as her own. She gathered families that were affected by the atrocities happening in northern Uganda in support groups and amplified their voices through her activism nationally and internationally (Katongole 2011:148-165).

- In Burundi, Maggy Barankitse has been tangibly challenging the dominant narrative of hatred and separation between the Hutus, Tutsis and Twas. She went about it by raising children from these ethnic groups under the same roof as her own. She later on founded House shalom to expand her capacity to care of these children. She even extended her hospitality to refugee children from the Congo (DR) and Rwanda (Katongole 2011:166-192).

These individuals have been tangibly preaching the message of love beyond borders. In order for such teachings to expand, a prophetic imagination leading to action is needed. Jackson et al. (1985) capture the essence of love agency in the song, 'We are the world', in which many world-renowned musicians worked collaboratively to raise funds to combat famine in Africa. In this song, they are calling the whole world to be in solidarity with those who suffer because 'we all are the world'.

As a missional team, we have been inspired by Michael Jackson and his fellows. We aim to be agents of love who go beyond the boundaries of our context of Soshanguve. This aim has influenced how we develop and nurture leadership for the church.

\section{About leadership development for the church}

Theological education is the traditional channel through which Christian leadership is trained and developed.

Theological education institutions are also a representation of the nepotistic entity the church has alienated itself into. De Beer and van Niekerk (2017:216-217) think that the purpose of theological education, especially at public institutions, should be 'to serve the public good in the broadest possible sense'. Learning from this opinion, our missional team leadership formation aims to form community developers. At a recent graduation event, Mamokgethi Phakeng (2019), the vice-chancellor of the University of Cape Town, challenged all the graduates present, including theologians:

I challenge you to use your education, this precious gift, to help achieve the dream of a future that is more just, equal and fair to make it inclusive for all. (p. 1). 
Talking to fellow African theologians, Mashau (2018:3) stresses that 'our preoccupations as theologians make us seek to distance ourselves from "ivory tower" or "desktop" research'. According to him, theologians need to figure out how 'to respond to the pain and suffering of those who are homeless and hopeless on the pavements and margins of our communities' (Mashau 2018:3).

Along the same line, Oduyoye (1986:9) stresses that theological education in Africa should train people to prioritise the public and common good of all Africans over 'denominational and other loyalties'. In addition, it should help trainees 'provide answers to this question: What is the church stance vis-à-vis the political, economic, and social changes around Africa?' (Oduyoye 1986:9). Such education would see activism for the common good as part of the mission of the church. Perkins (1993:18) opines that the gospel is 'to reconcile alienated people to God and to each other, across racial, cultural, social and economic barriers'. Such reconciliation sometimes requires some activism from the church such as the stance some denominations took to fight against the oppressive system of apartheid in South Africa.

Van Niekerk (2015:17) points out that in the seventies and eighties, the church in South Africa was activist'. Prominent ministers such as Desmond Tutu and Alan Boesak were some of the faces of church activism. They prioritised the good common good over their individual or family benefits. Until today, Tutu (2011) challenges the church to play an activist role in society as a servant leader. He uses an allegoric story to say: 'if an elephant has its foot on the tail of a mouse and you say that you are neutral, the mouse will not appreciate your neutrality' (Tutu 2004:55). He goes to an individual level and adds that individual Christian activists can inspire others to promote human rights, justice and freedom. He stresses that God calls the body of Christ to partner with him in building a loving and caring society 'where people will matter more than possessions... where there will be more gentleness, more caring, more sharing, more compassion, more laughter; where there is peace and not war (Tutu 2004:64)'.

Reverend Allan Boesak is also well known for his activism during apartheid in South Africa. He encourages Christian leadership to be selfless. He states that (Boesak 2011):

$[W]$ herever human beings rise above themselves and find the courage to work for genuine justice and humanity, God is at work, for that is the will of God for humanity. (p. 8)

He connects Christian activism to discipleship. According to Boesak (2011):

[W]e are disciples of Christ when we stand by God in the hour of God's grieving. The grieving of God... is the pain of God in the suffering of humanity. That pain inflicted by people on people is inflicted upon God. (p. 8)

The activism of Tutu and Boesak shows a prophetic role that Christian leadership played in society then and is still called to play in our post-modern society. De Beer (2019:5) hopes that 'the well-being of the common good becomes a primary referent for' Christian leadership. In addition, Christian leadership should 'resist, subvert and overthrow all that seeks to deplete the common good in favour of narrow self-interest' (de Beer 2019:5). Such practices would allow it 'to work tirelessly for flourishing humanity, local communities and societies at large' (de Beer 2019:6). The activism of these leaders showed a theology that was as big as South Africa. They understood that using the gospel in a way that transcends their spiritual tribe (denomination) would help 'free ourselves black people from the inferiority complex imposed by a system that apportioned value and human dignity according to a colour code' (Ramphele 2017:22). If today our church were to internalise this message, its position in society will be similar to what Senzo (2012) says in his song, I'll be there:

When you need a shoulder to cry on

You should know that you can lean on me every step of the way, I'll there.

You can count on me, I am the one who cares.

Your joy is my business,

Your pain is my business.

Just call me wherever I'll there.

Just call me day and night.

I'll there just as long as you still want me.

I'll be there just as long as you still need. (p. 1)

Christian leadership should prepare people to exercise such a role in society by embracing diversity and being inclusive in its service to society. Such an approach would give integrity to the church as the ambassador of the message of love as captured in Jesus' legacy statement to his disciples in John 13:33-35.

\section{Conclusion}

This article pointed out the reality of Christian leadership transfer that seems to run in the family as observed in many local churches located in the township of Soshanguve. Nepotism in church leadership has been normalised as it is prevalent in the society around them. Many ordinary church members have even internalised and accepted it as normal. The leadership-transfer reality hurts the prophetic role of the church in society. Music seems to be a medium well-suited to remind the church about what it means to not be nepotistic by being diverse, inclusive and involved in the societal matters. Yet, this medium of communication has been polarised into Christian and non-Christian. Christians are strongly discouraged from listening to non-Christians and therefore miss out on a kingdom-like message one could learn from or be reminded about. Music from people like Bobi Wine, Alpha Blondy, Muhindo Kasereka and Senzo contains kingdom-like values. Their meaning conveys the message of love Africa needs today. In its leadership formation, InnerCHANGE exposes its apprentices to this music with the hope of developing them as community builders and agents of love. 


\section{Acknowledgements Competing interests}

The author declares that he has no financial or personal relationships that may have inappropriately influenced him in writing this article.

\section{Author's contributions}

K.T.L.K. is the sole contributor to this work.

\section{Ethical considerations}

This article followed all ethical standards for a research without direct contact with human or animal subjects.

\section{Funding information}

This research received no specific grant from any funding agency in the public, commercial or not-for-profit sectors.

\section{Data availability statement}

Data sharing is not applicable to this article as no new data were created or analysed in this study.

\section{Disclaimer}

The views and opinions expressed in this article are those of the author and do not necessarily reflect the official policy or position of any affiliated agency of the author.

\section{References}

Bakke, R.J., 2009, A theology as big as the city, InterVarsity Press, Downers Grove, IL. Beti, M., 1977, King Lazarus, African Writers Series 77, Heinemann, London.

Bloom, J., 2017, Five marks of a servant leader, viewed 12 April 2019, from https:// www.desiringgod.org/articles/five-marks-of-a-servant-leader.

Bizfluent, 2019, viewed 15 May 2019, from https://bizfluent.com/info-8675655-proscons-nepotism-workplace.html.

Blondy, A., 2013, viewed 02 January 2016, from https://www.youtube.com/ watch? $v=7 \mathrm{mNecGZ6WkE}$

Boesak, A.A., 2011, “"For the tyrant shall be no more": Reflections on and lessons from "the Arab Spring" in North Africa, the Middle East and the civil rights and antiapartheid struggles', HTS Teologiese Studies/ Theological Studies 67(3), Art. \#1159, 9 pages. https://doi.org/10.4102/hts.v67i3.1159

Brueggemann, W., 2001, The prophetic imagination, 2nd edn., Fortress press, Minneapolis, MN.

Clinton, J.R., 1988, The making of a leader. Recognizing the lessons and stages of leadership development, NavPress, Colorado Springs, CO.

De Beer, S., 2008, 'Contesting inner-city space: Global trends, local exclusion/s and an alternative Christian spatial praxis', Missionalia 36(2/3), 181-207.

De Beer, S.F., 2019, 'Faith-based agency and theological education: A failed opportunity?', HTS Teologiese Studies/ Theological Studies 75(4), a5541. https:// doi.org/10.4102/hts.v75i4.5541

De Beer, S.F. \& Van Niekerk, A.S., 2017, “"Transforming curricula into the next century: Doing theology collaboratively with local communities", in "theology at the University of Pretoria - 100 years: (1917-2017) past, present and future"', Verbum et Ecclesia 38(4), a1683. https://doi.org/10.4102/ve.v38i4.1683

Donovan, V.J., 2005, Christianity rediscovered, Twenty-fifth anniversary edition, Orbis Books, New York, NY.

Du Toit, N., 2010, 'Action or apathy? "Theological perspectives and their influence on the church's engagement with poverty",' in I. Swart, H. Rocher, S. Green \& J. Erasmus (eds.), Religion and social development in post-apartheid South Africa. Perspectives for critical engagement, 1st edn., pp. 431-446, Sun Press, Stellenbosch.

Frost, M. \& Hirsch, A., 2003, The shaping of things to come. Innovation for the 21st century church, Hendrickson publishers, Peabody, MA.
Gibson, W.T., 1993, 'Nepotism, family, and merit: The Church of England in the eighteenth century', Journal of Family History 18(2), 179-190. https://doi.org/ $10.1177 / 036319909301800201$

Greenleaf, R.K., 2002, Servant leadership: A journey into the nature of legitimate power and greatness, Paulist Press, Mahwah, NJ.

Hilary, R.B., 1978, 'The nepotism of pope Pius II, 1458-1464', The Catholic Historical Review 64(1), 33-35.

Hirsch, A. \& Ford, L., 2011, Right here right now. Everyday mission for everyday people, Bakerbooks, Grand Rapids, MI.

Jackson, M., 1985, viewed 28 May 2019, from https://www.youtube.com/ watch?v=P2H6mpUnsLI.

Jaskiewicz, P., Uhlenbruck, K., Balkin, D.B. \& Reay, T., 2013, 'Is nepotism good or bad? Types of nepotism and implications for knowledge management', Family Business Review 26(2), 121-139. https://doi.org/10.1177/0894486512470841

Joffe, A.H., 2004, 'Nepotism for all times', Society-New Brunswick 41(6), 74-79. https://doi.org/10.1007/BF02688236

Kabongo, K.T.L., 2019a, 'From victimhood to hubs of (trans)formation and local agency: Re-imagining poor urban communities', Verbum et Ecclesia 40(1), a1998. https://doi.org/10.4102/ve.v40i1.1998

Katongole, E., 2011, The sacrifice of Africa. A political theology for Africa, William B. Eerdmans publishing company, Grand Rapids, MI

Katongole, E., 2017, Born from lament. The theology and politics of hope in Africa, William B. Eerdmans publishing company, Grand Rapids, MI.

Lester, B., Postlewaite, A. \& Wright, R., 2011, 'Information and liquidity', Journal of Money, Credit and Banking 43(S2), 355-377. https://doi.org/10.1111/j.1538-4616. 2011.00440.x

Maathai, W., 2009, The challenge for Africa. A new vision, William Heinemann, London.

Maluleke, T.S., 2008, 'May the black God stand, please! Biko's challenge to religion', in C.W. Du Toit (ed.), The legacy of Stephen Bantu Biko: Theological challenges, University of South Africa, pp. 115-126, Research Institute for Theology and Religion, Pretoria.

Mashau, T.D., 2018, 'Standing where God stands. JNJ Kritzinger as an encountering missionary and missiologist', Missionalia 46(1), 131-145.

Mashau, T.D. \& Kgatle, M.S., 2019, 'Prosperity gospel and the culture of greed in post-colonial Africa: Constructing an alternative African Christian theology of Ubuntu', Verbum et Ecclesia 40(1), a1901. https://doi.org/10.4102/ve. v40i1.1901

Mbembe, A., 2017, Critique of black reason, transl. L. Dubois, Duke University Press, Durham.

Mofokeng, T.A., 1987, 'A black Christology: A new beginning', Journal of Black Theology in South Africa 1(1), 1-17.

Muhindo, M.F., 2018, Pas de president, viewed 21 April 2019, from https:// soundcloud.com/lucha-rdcongo/pas-de-president-chanson-par-muhindomasimengo-fabrice-alias-fb-faba.

Mwambazambi, K., 2011, 'A missiological refection on African ecclesiology', Verbum et Ecclesia 32(1), Art. \#482, 8 pages. https://doi.org/10.4102/ ve.v32i1.482

Mwambazambi, K. \& Banza, A.K., 2014, 'Developing transformational leadership for sub-Saharan Africa: Essential missiological considerations for church workers', Verbum et Ecclesia 35(1), Art. \#849, 9 pages. https://doi.org/10.4102/ ve.v35i1.849

News24, 2019, viewed 12 June 2019, from https://www.news24.com/SouthAfrica/ News/release-king-dalindyebo-from-prison-traditional-leaders-toramaphosa-20190407.

Oakland, R., 2013, Sins of the fathers, nepotism, and apostasy in the church, viewed 29 April 2019, from https://www.understandthetimes.org/commentary/c209pf. shtml.

Perkins, J.M., 1993, Beyond charity. The call to Christian community development, BakerBooks, Grand Rapids, MI.

Oduyoye, M.A., 1986, Hearing and knowing. Theological reflections on Christianity in Africa, Orbis Books, Maryknoll, NY.

Perkins, J.M., 2014, Let justice roll down, BakerBooks, Grand Rapids, MI.

Phakeng, M., 2019, Graduation April 2019, viewed 01 June 2019, from https://bit. ly/2Vyrnmw.

Polit, D.F. \& Beck, C.T., 2008, Nursing research. Generating and assessing evidence for nursing practice, 8th edn., Lippincott Williams \& Wilkins, Hong Kong.

Pretoria News, December 2011, viewed 04 December 2018, from https://www. pressreader.com.

Ramphele, M., 2017, Dreams, betrayal and hope, Penguin Books, Cape Town.

Russell, R.F., 2001, 'The role of values in servant leadership', Leadership \& Organization Development Journal 22(2), 76-84. https://doi.org/10.1108/01437730110382631

Senzo (Eugene Ndela), 2012, viewed 02 June 2019, from https://www.youtube.com/ watch?v=PG11V_UPgVs.

Shaw, P.W., 2006, 'Vulnerable authority: A theological approach to leadership and teamwork', Christian Education Journal 3(1), 119-133. https://doi.org/10.1177/ 073989130600300109

Soyinka, W., 1972, 'Interview', in D. Duerden \& C. Pieterse (eds.), African writer talking, pp. 11-13, Heinemann, London. 
Spears, L.C., 2010, 'Character and servant leadership: Ten characteristics of effective, caring leaders', The Journal of Virtues \& Leadership 1(1), 25-30.

Tshilenga, E., 2016, Leadership interactive Bible studies. Sharing of twenty seven biblical leaders, Libs, Pretoria.

Tutu, D., 1999, No future without forgiveness, Doubleday, New York, NY.

Tutu, D., 2011, God is not a Christian: And other provocations, Harper Collins, New York, NY.
Tutu, D. \& Douglas, A., 2004, God has a dream. A vision of hope for our time, Doubleday, New York, NY.

Van Niekerk, A., 1994, Ubuntu and religion, Ubuntu School of Philosophy, Pretoria.

Van Niekerk, A., 2015, Module GSW 310/314, Faculty of Theology and Religion, University of Pretoria, Pretoria.

Wine, B.H.E., 2017, viewed 12 April 2019, from https://www.youtube.com/watch? $v=j 3$ rjOMVQgus. 